Egyptian Journal of Aquatic Biology \& Fisheries

Zoology Department, Faculty of Science,

Ain Shams University, Cairo, Egypt.

ISSN $1110-6131$

Vol. 24(3): 403 - 415 (2020)

www.ejabf.journals.ekb.eg

\title{
Genetic diversity and phylogenetic reconstruction of grouper (Serranidae) from Sunda Land, Indonesia
}

\author{
Sapto Andriyono ${ }^{1 *}$, Adrian Damora ${ }^{2}$, Andi A. Hidayani ${ }^{3}$ \\ ${ }^{1}$ Department of Marine, Fisheries and Marine Faculty, Universitas Airlangga C Campus Jl. \\ Mulyorejo Surabaya East Java, 60115, Indonesia \\ ${ }^{2}$ Department of Aquaculture, Faculty of Marine and Fisheries, Universitas Syiah Kuala, Jl. Putroe \\ Phang, Darussalam, Banda Aceh 23111, Aceh, Indonesia \\ ${ }^{3}$ Fisheries Department, Faculty of Marine Science and Fisheries, Hasanuddin University. Jl. \\ Perintis Kemerdekaan KM. 10, Makassar, South Sulawesi, Indonesia. \\ *Corresponding Author: sapto.andriyono@fpk.unair.ac.id
}

\section{ARTICLE INFO}

Article History:

Received: May 7, 2020

Accepted: May 25, 2020

Online: May 29, 2020

Keywords:

Commercial groupers,

Serranidae,

Genetic study,

Sunda land,

Indonesia

\begin{abstract}
Groupers are coral reefs associated and favored in the aquaculture industry. Aquaculture system has been successfully carried out with a floating cage system as well as in an aquaculture system in a pond. Lately, breeding activities in groupers have produced hybrid species that are expected to increase production and fulfillment of the demand of groupers in the live fish market in Singapore, Taiwan, and China. The study of biology has supported the success of many of groupers, but information on genetic variation in commercial groupers is still very limited. This report is a preliminary study of genetic diversity in commercial groups from Java, Bali, and Aceh, which is the Sunda land region in western Indonesia. Eleven specimens have been identified with the barcode region (Cytochrome c Oxidase subunit I gene region). As a result, two species were identified as Indonesian haplotypes, namely Epinephelus merra and Cephalopholis cyanostigma. Phylogenetic tree analysis produces two large clades, namely Clade I (Epinephelus) and Clade II (Cephalopholis and Variola), which are clearly separated in the subfamily Epinephelinae. However, in-depth studies of genetic variation need to be more accurate by increasing the number of specimens from various regions in Indonesia to describe genetic diversity comprehensively.
\end{abstract}

\section{INTRODUCTION}

A grouper is a group of fish that inhabit in the coral reef ecosystems and rocky shallow waters as their primary habitat. Several species found in shallow waters that have sandy mud substrate, which makes the grouper habitat variation quite diverse. The diversity of grouper habitat also makes groupers have a variety of species. As reported in previous studies, the waters of Bali have Serranidae diversity of 54 species or about 5.5 $\%$ of the composition of reef fish (Allen and Erdmann, 2013). Other studies reported 
that the Epinephelinae subfamily has 159 species, including 15 genera of Cephalopolis and 31 genera of Epinephelus (Allen and Adrim, 2003).

Groupers are an intimate group in the aquaculture industry because it can reach a significant size in weight of up to $400 \mathrm{~kg}$ and the total length of 2.5 meters (Heemstra, 1993), this fish became an essential commodity of aquaculture in Asia and some countries in the world (Chiu et al., 2008), both with floating net systems and in ponds that show an increase of 8-16\% starting in the 1900s (Pomeroy, 2002). The high demand for grouper, both for consumption and for ornamental fisheries, makes grouper aquaculture more attractive with high market prices and export-oriented (Halim, 2001). The Indo-Malayan Archipelago region plays a vital role in the grouper supply chain worldwide. It has been estimated that about $80 \%$ of the world's production of groupers was reported from Asia, mainly from Indonesia, the Philippines and Malaysia with a steadily increasing number of products every year (Craig et al., 2011; Sadovy de Mitcheson et al., 2013; Yulianto et al., 2015; Alcantara and Yambot, 2016; and Kadir et al., 2018). Increased export values have been felt since 1980, with export values to several Asian countries (Singapore, Hong Kong, and China) (Nuraini and Hartati, 2006), United States, and Europe (Halim, 2001). The high level of human exploitation of groupers causes at least one-third of the genus of the subfamily Epinephelinae, especially the Epinephelus and Mycteroperca genera listed as endangered species (Morris et al., 2000) and requires very strict licensing and approval. For example, the giant groupers $(E$. lanceolatus) and the Napoleon wrasse (C. undulatus), have become vulnerable fish since they were established in 1996 by IUCN (Halim, 2001). In addition, out of 163 grouper species across the globe, $12 \%$ (20 species) are at risk of extinction, and $13 \%$ (22 species) are considered to be nearly threatened based on the IUCN Red List criteria (Craig et al., 2011).

The limitations of the study of phylogenetic relationships between fish in subfamily Epinephelinae (Epinephelus, Serranidae) are still vital, given the complexity of the members of this family (Craig and Hastings, 2007). Epinephelus distribution is quite extensive, around the Indo-west Pacific and Indo-Pacific (Heemstra and Randall, 1993; Van Herwerden et al., 2002; and Unsworth et al. 2007). In general, people only mention groupers, which are indicated by the spots on their body parts. The fish have a brownish to attractive red colour associated with their diverse habitats from shallow water areas and very colourful coral reef ecosystems (Unsworth et al., 2007)

DNA barcoding believed to be one of the methods used globally to identify molecular approaches for animals and plants. This identification, the DNA in mitochondrial, becomes a remarkable sequence that is considered capable of being a marker and has been accepted as a global bio-identification system for animals (Hebert et al., 2003 and Ward et al., 2005). This identification is beneficial in specimens that are difficult to identify morphologically, such as larval stage, and organ fragments or morphologically incomplete specimens (Hebert et al., 2003). Various advantages of DNA coding are straightforward and useful universal tools that include all the animals both in the form of fresh and processed product samples (Pepe et al., 2007 and Giusti $\boldsymbol{e t}$

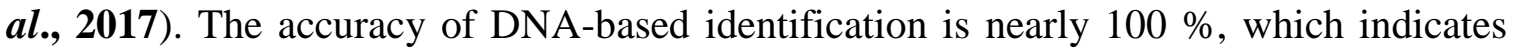
that this method can prove the identification of specimens under different environmental conditions (Meyer and Paulay, 2005). The barcoding system uses sequences that have a diversity in the single region of mitochondrial DNA, cytochrome c oxidase subunit I gene 
(COI), and then deposited to the GenBank database. The GenBank has become central to deposit diverse taxes from all parts of the world. With the increase of molecular databases, scientists have demonstrated their effectiveness in conducting DNA barcoding from freshwater fish to deep-sea fish (Ward et al., 2005 and Lakra et al., 2011). Previous research has shown that mitochondrial DNA has a higher mutation rate compared to nuclear DNA by inheriting the maternal gene. Thus, researchers can obtain handy data for studying evolution between species, even within the same species (Waugh, 2007). In this research, we performed the molecular identification of several grouper from seven sampling sites (Java, Bali Island, and Aceh) with the COI gene region to understand the diversity and measure the genetic distance of each species, especially in the genus Epinephelus, Cephalopholis, and Variola.

\section{MATERIALS AND METHODS}

\section{Sampling site}

A total of 8 fish samples were collected from the five traditional fish markets around Jawa Island during July 2019. In the northern part of Java, samples were obtained from the Banten $\left(6^{\circ} 0^{\prime} 50.00^{\prime} \mathrm{S}-106^{\circ} 10^{\prime} 21.00^{\prime \prime} \mathrm{E}\right)$, and Gresik $\left(6^{\circ} 52^{\prime} 56.65^{\prime} \mathrm{S}\right.$ $\left.112^{\circ} 12^{\prime} 15.87^{\prime \prime}\right)$, while Southern Java was represented samples from Malang $\left(8^{\circ} 26^{\prime} 06.65^{\prime} \mathrm{S}-112^{\circ} 40^{\prime} 55.31^{\prime \prime}\right)$, the Banyuwangi $\left(8^{\circ} 12^{\prime} 07.52^{\prime} \mathrm{S}-114^{\circ} 23^{\prime} 07.18^{\prime \prime} \mathrm{E}\right)$, and Bali $\left(8^{\circ} 45^{\prime} 23.00^{\prime} \mathrm{S}-115^{\circ} 10^{\prime} 05.68^{\prime \prime} \mathrm{E}\right)$. Here, we also collected a specimen from the Kutaradja fish traditional market in Aceh, the westernmost province of Sumatera $\left(5^{\circ} 35^{\prime} 07.00^{\prime} \mathrm{N}-95^{\circ} 19^{\prime} 07.00^{\prime \prime} \mathrm{E}\right)$. Morphologically identification conducted according to the guideline from FAO (Heemstra, 1993), and species confirmation has been carried out with molecular identification carried out in this study using the COI gene region. No specific permit was required for this study due to collect from the local traditional fish market were dead upon purchasing. Before dissected, all specimen has been photographed by the digital camera.

\section{DNA extraction and PCR}

Each specimen has been collected and directly preserved in $90 \%$ ethanol for further experimental purposes. Around one $\mathrm{cm}$ tissues was taken from the anal fin of each specimen, dissected and mix with 6X lysis buffer, which was further homogenized by the TissueLyser II (Qiagen). Genomic DNA extracted using an Accuprep ${ }^{\circledR}$ Genomic DNA Extraction Kit (Bioneer) according to the manufacturer's guidelines. Quantification of purified genomic DNA performed by Nanodrop (Thermofisher Scientific D1000), aliquoted and stored at $-70^{\circ} \mathrm{C}$ for further analysis.

\section{PCR condition and Data Analysis}

One set of universal fish primer targeting cytochrome c oxidase I (COI) region, FISH-BCL (5'-TCA ACY AAT CAY AAA GAT ATY GGC AC-3') and FISH-BCH (5'TAA ACT TCA GGG TGA CCA AAA AAT CA-3') (Baldwin $\boldsymbol{e t}$ al., 2009 and Handy et al., 2011), used to obtain the partial sequences of COI gene. The PCR mixture $(20 \mu \mathrm{L})$ included $11.2 \mu \mathrm{L}$ ultra-pure water, $1 \mu \mathrm{L}$ primer forward and reverse $(0.5 \mu \mathrm{M}), 0.2 \mu \mathrm{L}$ Ex Taq DNA polymerase (TaKaRa, Japan), $2 \mu \mathrm{L}$ 10X ExTag Buffer, $2 \mu \mathrm{L}$ dNTPs $(1 \mu \mathrm{M}$, TaKaRa, Japan), and $2 \mu \mathrm{L}$ genomic DNA as template. The PCR condition carried out 
under the following setting: $95^{\circ} \mathrm{C}$ for $5 \mathrm{~min}$ in initial denaturation, followed by denaturation at $95^{\circ} \mathrm{C}$ for $30 \mathrm{~s}$ in 40 cycles, $50^{\circ} \mathrm{C}$ for $30 \mathrm{~s}$ in annealing, and $72^{\circ} \mathrm{C}$ for $45 \mathrm{~s}$ in extension step, and a final extension at $72^{\circ} \mathrm{C}$ for $5 \mathrm{~min}$. The PCR products were purified with the AccuPrep ${ }^{\circledR}$ Gel purification kit (Bioneer, Korea).

\section{Phylogenetic analysis}

All sequences were aligned, including reference sequences from the GenBank database (Table 1). The pairwise evolutionary distance among the family determined by the Kimura 2-Parameter method. The Neighbor-joining (NJ) tree constructed, and 1000 bootstrap analysis was carried by Mega7 program (Kumar et al., 2016).

\section{RESULTS}

A total of 11 successful identification samples consisted of three genera, Epinephelus (5), Cephalopholis (3), Variola (1). In this study, the genus Epinephelus was more dominated the general catches of fishers, including $E$. coioides, $E$. ongus, E. poecilonotus, E. areolatus, E. merra. Meanwhile, other types are only in small quantities.

Tabel 1. The genetic distance of Epinephelinae compare to the reference from GenBank database

\begin{tabular}{lcc}
\hline Species name & $\begin{array}{c}\text { Genetic distance } \\
\text { within species }\end{array}$ & $\begin{array}{c}\text { Genetic distance } \\
\text { between species }\end{array}$ \\
\hline Clade I (Epinephelus) & & \\
$\quad$ E. areolatus & 0.000 & $0.152-0.181$ \\
E. merra & 0.004 & $0.157-0.185$ \\
E. ongus & 0.000 & $0.107-0.184$ \\
E. poecilonotus & 0.000 & $0.107-0.119$ \\
$\quad$ E. oioides & 0.000 & $0.119-0.181$ \\
Clade II (Cephalopholis and Variola) & & \\
$\quad$ C. miniata & 0.000 & $0.089-0.216$ \\
C. sonnerati & 0.000 & $0.089-0.174$ \\
C. cyanostigma & 0.002 & $0.150-0.202$ \\
V. albimarginata & 0.000 & $0.173-0.206$ \\
\hline
\end{tabular}

\section{Genetic distance}

Genetic distance analysis was carried out using Mega 7, which aligned all obtained queries (Table 1). The results of this analysis provide a description of the distance between species (interspecific) and in the same species (intraspecific). Epinephelus areolatus obtained from Aceh is not different from the reference sequences originating from Saudi Arabia (KU499597) by the genetic distance is zero. The same thing also happens to another genus Epinephelus, which also has genetic distance 0 with reference in the GenBank database except in E. merra. In E. merra there is a slight difference, although identification still refers to the same species. Genetic distance with specimens originating from Japan (AP005991) is only 0.004, indicating that E.merra species is an Indonesian haplotype. Whereas in Cephalopolis species, 
only $C$. cyanostigma was found in Indonesian haplotypes with a genetic distance of 0.002 with reference specimens from the Philippines (KU668647).

\section{Phylogenetic reconstruction}

In the phylogenetic tree produced, two clades have been formed consisting of the genus Epinephelus, and the other clade consists of Cephalopholis and Variola (Figure 1). Morphologically, the Epinephelus group is dark grey to dark brown, while Cephalopholis and Variola are bright red body-colour (Figure 2). Although morphologically, the two clades show differences, sometimes it is challenging for researchers and the public to distinguish each species. Besides, the giving of various regional names also adds to the complexity of naming. So that the molecular identification carried out in this study is expected to help ensure the types of fish identified and traded in traditional markets in several areas. The certainty of the name in the specie here is also essential in various scientific writings because it deals with scientific information that will be read by the general public, especially in academic purposes.

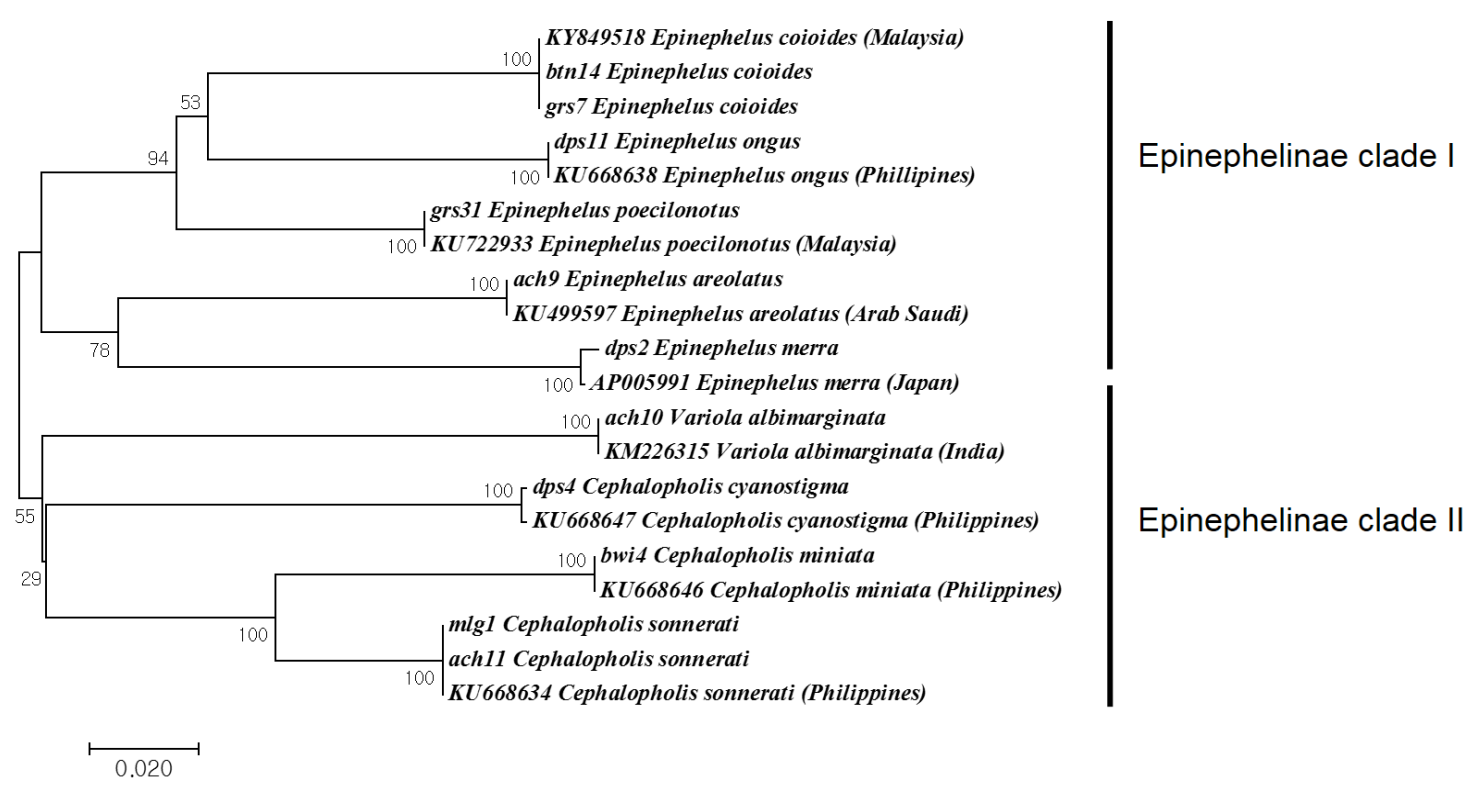

Figure 1. Phylogenetic tree of Epinephelinae including references from the GenBank database

\section{Epinephelinae status in IUCN and CITES}

Almost all grouper species in this study have the status of Least Concern (LC), while the grouper in international trade (CITES) is not evaluated (Table 2). However, $E$. merra has been reported as a causative agent of Ciguatera fish poisoning in several countries (Lewis, 1986). This fish poisoning occurs in some countries such as Thailand (Toyoda et al., 1981), the Philippines (Montojo et al., 2020), Hong Kong (Sadovy, 1997), Australia (Gillespie et al., 1986), and other countries (Randall, 1958; Chan 2015; and Gaboriau et al., 2014, ). However, there have been no reports of ciguatera in Indonesia (Chan, 2015). 
Tabel 2. IUCN and CITES status of all grouper specimens

\begin{tabular}{llllll}
\hline Species name & English name & Distribution & IUCN & CITES & Threat to humans \\
\hline E. areolatus & Areolate grouper & Indo-Pacific & LC & NE & Harmless \\
E. merra & Honeycomb grouper & Indo-Pacific & LC & NE & Reports of ciguatera poisoning \\
E. ongus & White-streaked grouper & Indo-West Pacific & LC & NE & Harmless \\
E. poecilonotus & Dot-dash grouper & Indo-West Pacific & LC & NE & Harmless \\
E. oioides & Orange-spotted grouper & Indo-West Pacific & LC & NE & Harmless \\
C. miniata & Coral hind & Indo-Pacific & LC & NE & Harmless \\
C. sonnerati & Tomato hind & Indo-Pacific & LC & NE & Harmless \\
C. cyanostigma & Blue-spotted hind & Western Pacific & LC & NE & Harmless \\
$V$. albimarginata & White-edged lyre tail & Indo-Pacific & LC & NE & Harmless \\
\hline
\end{tabular}

LC: Least Concern

NE: Not Evaluated

\section{DISCUSSION}

Grouper has become a leading commodity in aquaculture in several Asian countries and several other continents (Halim, 2001). The success of aquaculture is demonstrated by many studies on the reproductive biology that are sufficient detailed (Andrade $\boldsymbol{e t}$ al., 2003 and Andamari et al., 2007, ), hatchery (Rimmer, 2000, and Sugama et al. 2012), larval rearing to a variety of grow-up system (Fukuhara, 1989 and Pomeroy, 2002). Several studies have shown good results in hatching several species of groupers such as E. coioides, E. fuscoguttatus, Plectropomus leopardus, and Cromileptes altivelis (Rimmer, 2000), E. fuscoguttatus (Sugama et al., 2017). Research on the growup system also showed excellent results both in the floating net system (Baliao et al., 2000) and in the aquaculture system in the pond (Baliao et al., 1998).

Trade-in grouper in the live fish becomes a superior commodity because the price is quite high when compared to fresh dead fish. The demand for live fish forms continues to increase, so fishers prefer to sell live fish (Halim, 2001). However, many aquaculture activities are currently conducting such as breeding between species, which are expected to produce variants that have growth and other good traits such as disease resistance, good growth, resistance to extreme environments, and at the same time, making sterile fish (Hickling, 1968). For example, the crossing of tiger grouper and $E$. fuscoguttatus and $E$. polyphekadion grouper, which produce hybrid grouper with excellent growth performance (James et al., 1999). However, please note that the pure parent lines that will be breeding must be well known so that the study of this breeding effect can be done well. Other breeding was also developed on $E$. costae with $E$. marginatus (Glamuzina et al., 2001), Plectropomus leopardus with Plectropomus maculatus (Frisch and Hobbs, 2007), and E. coioides with E. lanceolatus (Kiriyakit et al., 2011 and Sutthinon et al., 2015). 

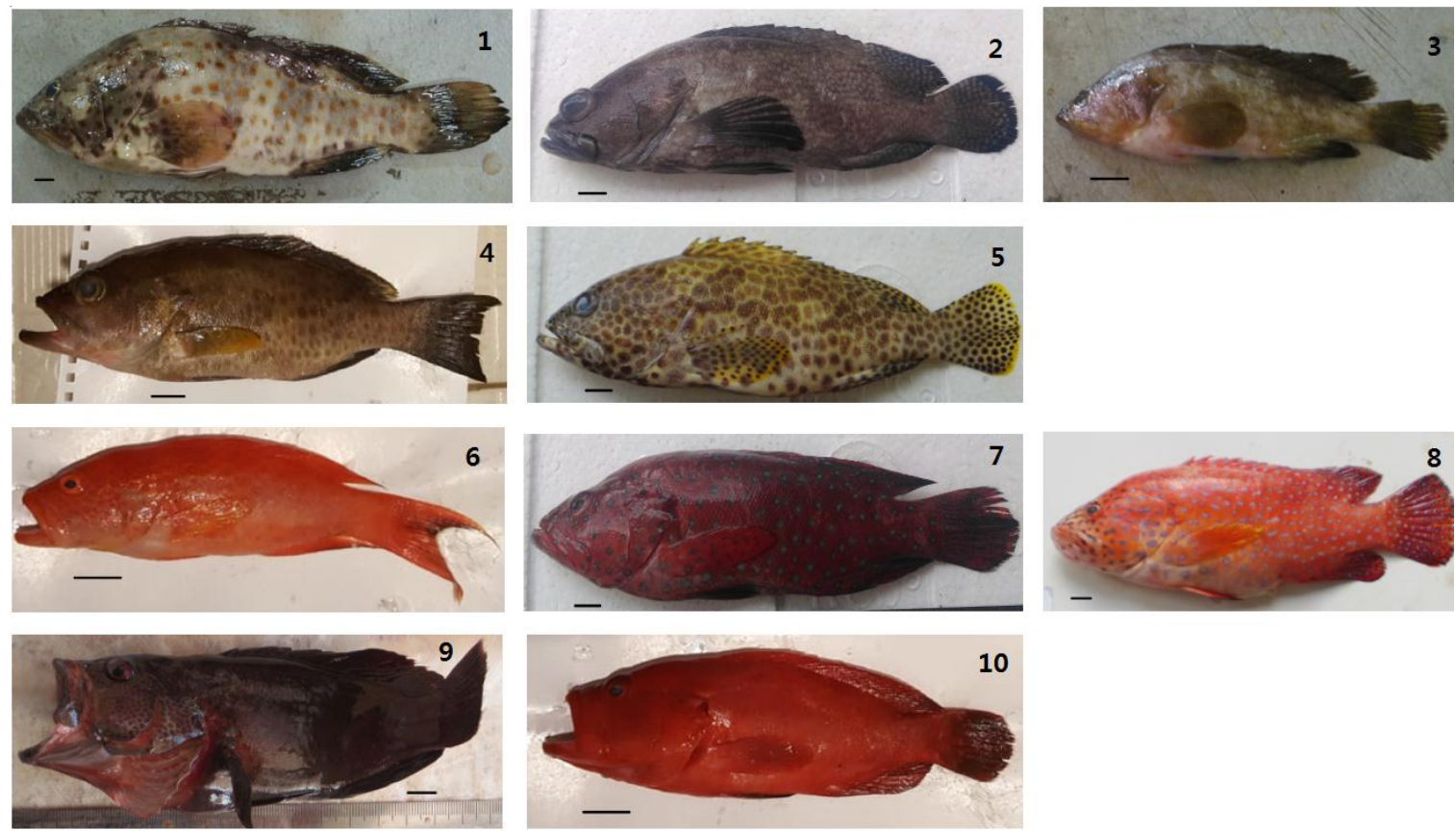

Figure 2. grs7 E. coioides(1); dps11 E.ongus (2); grs31 E. poecilonotus (3); ach9 E. areolatus (4); dps2 E. merra (5); ach10 Variola albimarginata (6); dps4 Cephalopholis cyanostigma (7); bwi4 C. miniata (8); mlg11 C. sonnerati (9) ; ach11 C. sonnerati (10)

Some breeding activities between Epinephelus species have been carried out in Indonesia. One of them is a hybrid between $E$. microdon (male) and $E$. fuscoguttatus (female) by producing seeds that have the title grouper cantik (Ismi, 2014). Another type of hybrid is the grouper cantang, which is a hybrid of $E$. fuscoguttatus and E. lanceolatus (Shapawi et al., 2019). Another hybrid type is the kustang grouper, which is breeding of Cromileptes altivelis with E. coioides (Yu et al., 2004). Breeding between $E$. microdon and $E$. lanceolatus has been carried out, which produces a new type of hybrid grouper (Sutarmat and Yudha, 2016). Also, back-cross hybrids have also been carried out between hybrids ( $E$. coioides $\mathrm{x} E$. lanceolatus) breeding with E. lanceolatus (Luan et al., 2016). Back-cross breeding efforts are carried out to produce seeds that are more productive and have the advantage of better traits such as a high survival rate than the previous generation.

Due to the intensive exploitation of grouper species in the world, only a small number of studies on the genetic diversity of the species have been carried out. In Indonesia, although intensive aquaculture activities are carried out, only a few types of grouper have been reported about genetic studies such as E. coioides (Antoro et al., 2006), E. siullus (Parenrengi and Tenriulo, 2008), Cromileptes altivelis (Susanto et al., 2011 and Sugama $\boldsymbol{e t}$ al., 2017 ) and several other types of grouper E. areolatus, E. merra, E. ongus, E. fasciatus, E. coioides, E. coeruleopunctatus, and E. longispinis (Jefri et al., 2015). Nevertheless, barcoding studies of several types of grouper have been carried out from some regions in Java and Bali (Andriyono et al., 2020), Makassar (Parenrengi and Tenriulo, 2008), Lampung and Papua (Jefri et al., 2015). This report is the first report involving specimens from Aceh and at the same time comparing with references from the GenBank database. 
The use of genetic information from the GenBank database provides a picture of the similarities between species groups, even though the species has a large habitat distribution in the Indo-Pacific region (Randall and Heemstra, 1991 and Unsworth et al., 2007). It is estimated, the grouper included in coral reef fish associated has experienced speciation that allows it to have variations in its genetic composition (Rocha and Bowen, 2008). Specialization of reef fishes has illustrated that open access sea also has its boundaries and niches so that many species will be different and adapt to each type of coral reef ecosystem. In this study, only two types (E. merra and C. cyanostigma) were found to be Indonesian haplotypes and differ from the same species from the alignment of the DNA reference sequence.

The distribution of E. merra is quite extensive with significant habitats found in the Indo-Pacific region including South Africa to French Polynesia and even in the central Pacific (Randall and Heemstra, 1991; Craig et al., 2011; and Muths and Bourjea, 2011) which generally inhabit waters bring ( $<20 \mathrm{~m}$ depth). Its natural habitat is a coral reef area and becomes essential in artisanal fisheries as a source of protein and food for coastal communities (Heemstra, 1993). Studies on E. merra diversity also indicate genetic variation in Madagascar, the Maldives, and small islands in the West Indian Ocean (Muths et al., 2015).

Meanwhile, $C$. cyanostigma was also identified in Maluku waters, which has a reasonably high diversity of the genus Cephalopolis with 11 species inhabiting the waters of this region (Limmon et al., 2017) and North Sulawesi (Tokeshi et al., 2013). Based on previous reports, the genus Cephalopholis consists of 22 species that have habitat distribution in the Pacific Ocean region (Heemstra, 1993), which tend to have a cryptic habit on coral reef ecosystems (Shpigel and Fishelson, 1989). Of the 22 known species of Cephalopholis, only nine species have been studied in terms of their biology. Many studies on several aspects of biology, including sexual maturity (Shapiro 1987), spawning (Donaldson, 1989), territoriality and their ecology (Shpigel and Fishelson, 1991), and sex change and population structure of Cephalopholis (Siau, 1994). Meanwhile, this report is the first report on genetic distance in C. syanostigma in Indonesia based on the COI sequences that show the existence of different haplotypes with the same species in the Philippines. The haplotype was formed due to geographical different, the Philippine species is an Indo West-pacific species, while the sample in this study is a species of the Indian ocean. This result needs to get attention for further research on genetic variation of Cephalopholis in Indonesian regions with a more significant number of samples.

The haplotypes found in $E$. merra and $C$. cyanostigma can be known by phylogenetic tree analysis, which shows a slight distance with sequence reference (Figure 1). This study is quite helpful in giving an idea of the haplotype formed. Also, through this phylogenetic tree, it is known that the genus Epinephelus forms a separate clade separating from Cephalopolis and Variola. In this study, Cephalopholis and Variola are in the same clade but separated in several branches. Morphologically, these two genera can be easily distinguished by observing the caudal fin (Figure 2). In Variola species have caudal fin lunate (Baldwin, 2003), than Cephalopholis have rounded caudal fin (Allen, 2015). Thus, the phylogenetic tree places the two genera in separate branches (Figure 1). Although the number of samples is still small, this report 
reinforces that the Epinephelinae group has several clades, which are genetic variations in the grouper.

\section{CONCLUSION}

In this study, we found genetic variation in E. merra and C. cyanostigma that showed the existence of Indonesian haplotypes. This result was figure-out genetic distance of some species in this report. The genetic distance of E. merra and C. cyanostigma are 0.004 and 0.002 , which is slightly different from sequences from Japan and the Philippines, respectively. It is necessary more in-depth studies of $C$. cyanostigma, due to the limited study of genetic variation, especially in Indonesia. The study of $C$. cyanostigma is very supportive in efforts to develop this species as an aquaculture commodity in the future, such as Epinephelus. An in-depth study of biological characteristics, including reproductive biology, ecology, and other specific characteristics, will be beneficial in both conservation and domestication.

\section{ACKNOWLEDGMENTS}

The authors would like to express our sincere gratitude for the initiation of collaborative research between Airlangga University (Surabaya), Syiah Kuala University (Aceh), and Hasanuddin University (Makassar) which have given great importance to the development of studies in Indonesia. Fisheries studies in Java, Sumatra, Sulawesi, Kalimantan, and Papua require the support of many collaborators to produce quality and beneficial research for Indonesia.

\section{REFERENCES}

Alcantara, S.G. and Yambot, A.V. (2016). DNA barcoding of commercially important grouper species (Perciformes, Serranidae) in the Philippines. Mitochondrial DNA Part A 27: 3837-3845.

Allen, G.R. (2015). Review of Indo-Pacific coral reef fish systematics: 1980 to 2014 . Ichthyological Research 62: 2-8.

Allen, G.R and Adrim, M. (2003). Coral reef fishes of Indonesia. ZOOLOGICAL STUDIES-TAIPEI- 42: 1-72.

Allen, G.R. and Erdmann, M.V. (2013). Reef Fishes of Bali, Indonesia. Bali Marine Rapid Assessment Program 2011, BioOne. 15-68.

Andamari, R.; Sembiring, S.B.M. and Permana, G.N. (2007). Aspects of leopard coral grouper (Plectropomus leopardus) reproduction in Indonesia. Indonesian Aquaculture Journal 2: 51-57.

Andrade, Á.B.; Machado, L.F.; Hostim-Silva, M and Barreiros, J.P. (2003). Reproductive biology of the dusky grouper Epinephelus marginatus (Lowe, 1834). Brazilian Archives of Biology and Technology 46: 373-382.

Andriyono, S.; Alam, M.J. and Kim, H.W. (2020). The Jawa and Bali Island Marine Fish Molecular Identification to Improve 12S rRNA-tRNA Valin-16S rRNA Partial Region Sequences on the GenBank Database. Thalassas: An International Journal of Marine Sciences: pp.1-14. 
Antoro, S.; Na-Nakorn, U. and Koedprang, W. (2006). Study of genetic diversity of orangespotted grouper, Epinephelus coioides, from Thailand and Indonesia using microsatellite markers. Marine Biotechnology 8: 17-26.

Baldwin, C.C. (2003). FAO Species Identification Guide for Fishery Purposes. The Living Marine Resources of the Western Central Pacific. Copeia: February 2003, Vol 2003, No.1, 212-214

Baldwin, C.C.; Mounts, J.H.; Smith, D.G. and Weigt, L.A. (2009). Genetic identification and color descriptions of early life-history stages of Belizean Phaeoptyx and Astrapogon (Teleostei: Apogonidae) with comments on identification of adult Phaeoptyx. Zootaxa 2008: $1-22$.

Baliao, D.D.; Franco, N.M. and Jamon, N.R.S. (2000). Grouper culture in floating net cages: Aquaculture Department, Southeast Asian Fisheries Development Center. 17pp.

Baliao, D.D.; De los Santos, M.A.; Rodriguez, E.M. and Ticar, R.B. (1998). Grouper culture in brackishwater ponds: Aquaculture Department, Southeast Asian Fisheries Development Center. 28pp.

Chan, T.Y. (2015). Ciguatera fish poisoning in East Asia and southeast Asia. Marine drugs 13: 3466-3478.

Chiu, S.T.; Tsai, R.T.; Hsu, J.P.; Liu, C.H. and Cheng, W. (2008). Dietary sodium alginate administration to enhance the non-specific immune responses, and disease resistance of the juvenile grouper Epinephelus fuscoguttatus. Aquaculture 277: 6672.

Craig, M.T. and Hastings, P.A. (2007). A molecular phylogeny of the groupers of the subfamily Epinephelinae (Serranidae) with a revised classification of the Epinephelini. Ichthyological Research 54: 1-17.

Craig, M.T.; de Mitcheson, Y.S. and Heemstra, P.C. (2011). Groupers of the world: a field and market guide: NISC Grahamstown. 424pp.

Donaldson, T.J. (1989). Pair spawning of Cephalopholis boenack (Serranidae). Japanese Journal of Ichthyology 35: 497-500.

Frisch, A. and Hobbs, J.P. (2007). In vitro hybridization of coral trouts, Plectropomus leopardus (Lacepede, 1802) and Plectropomus maculatus (Bloch, 1790): a preliminary investigation. Aquaculture Research 38: 215.

Fukuhara, O. (1989). A review of the culture of grouper in Japan. Bull. Nansei Reg. Fish. Res. Lab 22: 47-57.

Gaboriau, M.; Ponton, D.; Darius, H.T. and Chinain, M. (2014). Ciguatera fish toxicity in French Polynesia: size does not always matter. Toxicon 84: 41-50.

Gillespie, N.C.; Lewis, R.J.; Holmes, M.J.; Bourke, J.B.; Pearn, J.H.; Bourke, A.T. and Shields, W.J. (1986). Ciguatera in Australia: occurrence, clinical features, pathophysiology and management. Medical Journal of Australia 145: 584-590.

Giusti, A.; Armani, A. and Sotelo, C.G. (2017). Advances in the analysis of complex food matrices: Species identification in surimi-based products using Next Generation Sequencing technologies. PloS one 12: 1-18.

Glamuzina, B.; Glavić, N.; Skaramuca, B.; Kozul, V. and Tutman, P. (2001). Early development of the hybrid Epinephelus $\operatorname{costae}+\times$ E. marginatus ${ }^{\lambda}$. Aquaculture 198: 55-61.

Halim, A. (2001). Grouper culture: an option for grouper management in Indonesia. Coastal Management 29: 319-326.

Handy, S.M.; Deeds, J.R.; Ivanova, N.V.; Hebert, P.D.; Hanner, R.H.; Ormos, A.; Weigt, L.A.; Moore, M.M. and Yancy, H.F. (2011). A single-laboratory validated 
method for the generation of DNA barcodes for the identification of fish for regulatory compliance. Journal of AOAC International 94: 201-210.

Hebert, P.D.; Cywinska, A.; Ball, S.L. and Dewaard, J.R. (2003). Biological identifications through DNA barcodes. Proceedings of the Royal Society of London. Series B: Biological Sciences 270: 313-321.

Heemstra, P.C. (1993). Groupers of the world (Family Serranidae, Subfamily Epinephelinae). An annotated and illustrated catalogue of the grouper, rockcod, hind, coral grouper and lyretail species known to date. FAO species catalogue 16. $301 \mathrm{pp}$.

Heemstra, P.C. and Randall, J.E. (1993). Groupers of the world. FAO Fisheries synopsis no. 125 vol. Food and Agriculture Organization, Rome. 301pp.

Hickling, C.F. (1968). The farming of fish: Pergamon Press. 88pp

Ismi, S. (2014). Peningkatan produksi dan kualitas benih kerapu dengan program hybridisasi. Jurnal Oceanologi Indonesia 1(1): 1-5.

James, C.; Al-Thobaiti, S.; Rasem, B. and Carlos, M. (1999). Potential of grouper hybrid (Epinephelus fuscoguttatus x E. polyphekadion) for aquaculture. Naga, the ICLARM Quarterly 22: 19-23.

Jefri, E.; Zamani, N.P.; Subhan, B. and Madduppa, H.H. (2015). Molecular phylogeny inferred from mitochondrial DNA of the grouper Epinephelus spp. in Indonesia collected from local fish market. Biodiversitas Journal of Biological Diversity 16(2):254-263.

Kadir, N.H.A.; Piah, R.M. and Ambak, M.A. (2018). Population Characteristics of Areolate Grouper Epinephelus areolatus (Forsskål 1775) from Terengganu Waters, Malaysia. Asian Fisheries Science 31: 276-283.

Kiriyakit, A.; Gallardo, W.G. and Bart, A.N. (2011). Successful hybridization of groupers (Epinephelus coioides x Epinephelus lanceolatus) using cryopreserved sperm. Aquaculture 320: 106-112.

Kumar, S.; Stecher, G. and Tamura, K. (2016). MEGA7: molecular evolutionary genetics analysis version 7.0 for bigger datasets. Molecular biology and evolution 33: 1870-1874.

Lakra, W.; Verma, M.; Goswami, M.; Lal, K.K.; Mohindra, V.; Punia, P.; Gopalakrishnan, A.; Singh, K.; Ward, R.D. and Hebert, P. (2011). DNA barcoding Indian marine fishes. Molecular Ecology Resources 11: 60-71.

Lewis, N.D. (1986). Epidemiology and Impact of Ciguatera. Marine fisheries review: 6.

Limmon, G.V.; Rojoly, F.; Khouw, A.S; Manuputty, G. and Pattikawa J.A. (2017). The Diversity of Grouper (Epinephelinae) in Ambon Island, Maluku, Indonesia. Future Collaboration on Island Studies between Pattimura University and Kagoshima University: 23-29.

Luan, G.H.; Luin, M.; Shapawi, R.; Fui Fui, C. and Senoo, S. (2016). Egg development of backcrossed hybrid grouper between OGGG (Epinephelus coioides $\times$ Epinephelus lanceolatus) and giant grouper (Epinephelus lanceolatus). Int. J. of Aquatic Science 7: 13-18.

Meyer, C.P.; and Paulay, G. (2005). DNA barcoding: error rates based on comprehensive sampling. PLoS biology 3: e422.

Montojo, U.M.; Tanyag, B.E.; Perelonia, K.B.S.; Cambia, F.D. and Oshiro, N. (2020). Ciguatera in the Philippines: Examining Reef Fish Vectors and Its Causative 
Benthic Dinoflagellates in Visayan and Sibuyan Seas. The Philippine Journal of Fisheries 27: 19-29.

Morris, A.V.; Roberts, C.M. and Hawkins JP. (2000). The threatened status of groupers (Epinephelinae). Biodiversity \& Conservation 9: 919-942.

Muths, D. and Bourjea, J. (2011). Characterization of thirteen new polymorphic microsatellite markers from the honeycomb grouper Epinephelus merra. Conservation genetics resources 3: 629-631.

Muths, D.; Tessier, E. and Bourjea, J. (2015). Genetic structure of the reef grouper Epinephelus merra in the West Indian Ocean appears congruent with biogeographic and oceanographic boundaries. Marine Ecology 36: 447-461.

Nuraini, S. and Hartati, S. (2006). Type groupers (Serranidae) Bubu catch in the seas of the Saleh Bay, Sumbawa. Proceedings of the National Seminar on Fish IV, Jatiluhur. August 29-30.

Parenrengi, A. and Tenriulo, A. (2008). Genetic Variability and Population Structure of Grouper (Epinephelus suillus) from Makassar Strait and Bone Bay, South Sulawesi, Indonesia. Indonesian Aquaculture Journal 3: 77-87.

Pepe, T.; Trotta, M.; Di Marco, I.; Anastasio, A.; Bautista, J.M. and Cortesi, M.L. (2007). Fish species identification in surimi-based products. Journal of agricultural and food chemistry 55: 3681-3685.

Pomeroy, R.S. (2002). The status of grouper culture in Southeast Asia. SPC Live Reef Fish Information Bulletin: 22-26.

Randall, J.E. (1958). A review of ciguatera, tropical fish poisoning, with a tentative explanation of its cause. Bulletin of Marine Science 8: 236-267.

Randall, J.E. and Heemstra, P.C. (1991). Revision of Indo-Pacific groupers (Perciformes: Serranidae: Epinephelinae), with descriptions of five new species. Indo-Pacific Fishes 20, 1-332.

Rimmer, M. (2000). Review of grouper hatchery technology. SPC Live Reef Fish Information Bulletin 7: 14-19.

Rocha, L. and Bowen, B. (2008). Speciation in coral- reef fishes. Journal of Fish Biology 72: 1101-1121.

Sadovy de Mitcheson, Y.; Craig, M.T.; Bertoncini, A.A.; Carpenter, K.E.; Cheung, W.W.; Choat, J.H.; Cornish, A.S.; Fennessy, S.T.; Ferreira, B.P. and Heemstra, P.C. (2013). Fishing groupers towards extinction: a global assessment of threats and extinction risks in a billion dollar fishery. Fish and fisheries 14: 119-136.

Sadovy, Y. (1997). Ciguatera hits Hong Kong live reef fish trade. SPC Fish. Newsletter 83 (October-December), 26-28.

Shapawi, R.; Abdullah, F.C.; Senoo, S. and Mustafa, S. (2019). Nutrition, growth and resilience of tiger grouper (Epinephelus fuscoguttatus) $\times$ giant Grouper (Epinephelus lanceolatus) hybrid- a review. Reviews in Aquaculture 11: 1285-1296.

Shapiro, D.Y. (1987). Reproduction in groupers. Tropical snappers and groupers: biology and fisheries management: 295-327.

Shpigel, M. and Fishelson, L. (1989). Food habits and prey selection of three species of groupers from the genus Cephalopholis (Serranidae: Teleostei). Environmental Biology of Fishes 24: 67-73. 
Shpigel, M. and Fishelson, L. (1991). Experimental removal of piscivorous groupers of the genus Cephalopholis (Serranidae) from coral habitats in the Gulf of Aqaba (RedSea). Environmental Biology of Fishes 31: 131-138.

Siau, Y. (1994). Population structure, reproduction and sex- change in a tropical East Atlantic grouper. Journal of Fish Biology 44: 205-211.

Sugama, K.; Tridjoko, T.; Haryanti, H. and Cholik F. (2017). Genetic Variation and Population Structure in the Humpback Grouper, Cromileptes Altivelis, troughout its Range in Indonesian Waters. Indonesian Fisheries Research Journal 5: 32-38.

Sugama, K.; Rimmer, M.; Ismi, S.; Koesharyani, I.; Suwirya, K.; Giri, N. and Alava, V. (2012). Hatchery management of tiger grouper (Epinephelus fuscoguttatus): a best-practice manual: Australian Centre for International Agricultural Research (ACIAR). 66pp.

Susanto, A.H.; Nuryanto, A. and Soedibja, P.H.T. (2011). Phylogeography and Genetic Diversity of Humpback Grouper Cromileptes altivelis based on Cytochrome C Oxidase I. Jurnal Natur Indonesia 14: 47-51.

Sutarmat, T. and Yudha, H.T. (2016). Analisis keragaan pertumbuhan benih kerapu hibrida hasil hibridisasi kerapu macan (Epinephelus fuscoguttatus) dengan kerapu kertang (Epinephelus lanceolatus) dan kerapu batik (Epinephelus microdon). Jurnal Riset Akuakultur 8: 363-372.

Sutthinon, P.; Thongprajukaew, K.; Saekhow, S. and Ketmanee, R. (2015). Juvenile hybrid grouper (Epinephelus coioides $\times$ E. lanceolatus) are euryhaline and can grow in a wide range of salinities. Aquaculture International 23: 671-682.

Tokeshi, M.; Arakaki, S. and Daud, J. (2013). Consuming Diversity: Analysis of Seasonal Catch Patterns in Multispecies Artisanal Reef Fisheries in North Sulawesi, Eastern Indonesia 1. Pacific Science 67: 1-13.

Toyoda, M.; Kingkate, A.; Jaengsawang, C.; Thanissorm, W. and Halilamian, C. (1981). Survey of ciguatera and tetrodotoxin of blowfish in Thailand. Journal of Food Safety 3: 207-213.

Unsworth, R.K.; Powell, A.; Hukom, F. and Smith, D.J. (2007). The ecology of IndoPacific grouper (Serranidae) species and the effects of a small scale no take area on grouper assemblage, abundance and size frequency distribution. Marine Biology 152: 243-254.

Van Herwerden, L.; Davies, C. and Choat, J. (2002). Phylogenetic and evolutionary perspectives of the Indo- Pacific grouper Plectvopomus species on the Great Barrier Reef, Australia. Journal of fish biology 60: 1591-1596.

Ward, R.D.; Zemlak, T.S.; Innes, B.H.; Last, P.R. and Hebert, P.D. (2005). DNA barcoding Australia's fish species. Philosophical Transactions of the Royal Society of London B: Biological Sciences 360: 1847-1857.

Waugh, J. (2007). DNA barcoding in animal species: progress, potential and pitfalls. BioEssays 29: 188-197.

Yu, H-N.; Lin, X-T.; Liang, X-F.; Xu, Z-N. and Meng, Y-R. (2004). Growth of Cromileptes altivelis and Epinephelus coioides in closed recirculating aquacultural system Marine Sciences. 28(4):1-4.

Yulianto, I.; Hammer, C.; Wiryawan, B. and Palm, H. (2015). Potential and risk of grouper (Epinephelus spp., Epinephelidae) stock enhancement in Indonesia. Journal of coastal zone management 18: 1-9. 